Texas A\&M University-San Antonio

Digital Commons @ Texas A\&M University-San Antonio

Special Education Faculty Publications

College of Education and Human Development

$11-2018$

\title{
Helping Students Make Informed Decisions About Transition Via Web-Based Resources
}

\author{
Dawn A. Rowe \\ University of Oregon \\ John McNaught \\ James Mason University \\ Louise Yoho \\ Claremont Graduate University \\ Mariya T. Davis \\ Texas A\&M University-San Antonio, Mariya.Davis@tamusa.edu \\ Mazzotti Mazzotti \\ University of Oregon
}

Follow this and additional works at: https://digitalcommons.tamusa.edu/sped_faculty

Part of the Disability and Equity in Education Commons, Educational Technology Commons, and the Special Education and Teaching Commons

\section{Repository Citation}

Rowe, Dawn A.; McNaught, John; Yoho, Louise; Davis, Mariya T.; and Mazzotti, Mazzotti, "Helping Students Make Informed Decisions About Transition Via Web-Based Resources" (2018). Special Education Faculty Publications. 2.

https://digitalcommons.tamusa.edu/sped_faculty/2

This Article is brought to you for free and open access by the College of Education and Human Development at Digital Commons @ Texas A\&M University- San Antonio. It has been accepted for inclusion in Special Education Faculty Publications by an authorized administrator of Digital Commons @ Texas A\&M University- San Antonio. For more information, please contact deirdre.mcdonald@tamusa.edu. 
Tools for Success: Helping Students with Disabilities Make Informed Decisions about Transition

Dawn A. Rowe, Ph.D.

University of Oregon

drowe3@uoregon.edu

541-346-8412

John McNaught, M.Ed.

James Mason University

mcnaugjt@jmu.edu

Louise Yoho, Ph.D.

Claremont Graduate University

louise.yoho@cgu.edu

Mariya Davis, Ph.D.

Texas A \& M University

MariyaDavis@msn.com

Valerie L. Mazzotti, Ph.D.

University of Oregon

vmazzott@uoregon.edu 


\begin{abstract}
Transition can be difficult for students with and without disabilities as they move to independent living after high school. Although there are many transitions that occur in a young person's life, transition from high school to adulthood is one of the most significant. One of the primary goals of special education is to improve post-school outcomes for students with disabilities; however, post-school outcomes for students with disabilities remain a critical area in need of improvement. Taking into account these poor outcomes, it becomes imperative for teachers to be able to guide their students in making informed decisions as they begin the transition process. This article provides teachers with reputable web-based resources to help youth build autonomy and gain information to support the transition from high school into post-school life.
\end{abstract}

Keywords: transition, high school students, disabilities. 
Tools for Success: Helping Students with Disabilities Make Informed Decisions about Transition Ms. Perez works at Valley River High School. She has 14 students on her caseload ranging in age from 16 to 18-years-old (six freshman, five sophomores, three juniors). All of her students have developed one or more post-school goals in education and training, employment, and independent living. The students on Ms. Perez's caseload have been learning about selfadvocacy and self-determination. They are beginning to explore ways in which to become more independent by taking more of a leadership role in the transition planning process.

In life, individuals experience many transitions. As students, transitions occur when students move from elementary to middle school, middle to high school, high school to postsecondary education and training, employment, and independent living. Preparing for these transitions can be fun and exciting, but scary at the same time. It takes preparation, especially for students with disabilities. Decisions made early can impact what happens later in life. One essential, and federally mandated, requirement to facilitate a student's successful movement from school to adult life is providing effective transition services. Paraphrased from the Individuals with Disabilities Education Act (IDEA; 2004), transition services are defined as: A coordinated set of activities focused on improving academic and functional achievement of a student to facilitate movement from school to post-school education, employment, and independent living (20 U.S.C. § 1401 sec. 602 [34]).

To provide effective transition services, schools need to know how to (a) support students in becoming more autonomous by directing students to reputable resources to facilitate learning about what it means to transition and (b) assist them in making informed decisions regarding the next stages of life. Transition skills are essential as youth with disabilities participate meaningfully in activities related to school, work, and community. It is important to provide 
students with the knowledge and skills necessary to make informed choices, decisions, and set goals (Chan, Graham-Day, Ressa, Peters, \& Konrad, 2014).

Ms. Perez is working with her students to define appropriate transition services that will support them in reaching their post-school goals. She has discussed the flow of transition services, explaining that it all starts with transition assessment data. Students have engaged in a variety of assessments to identify strengths, needs, interests, and preferences, and have developed measurable post-school goals. For example, Michah, a $10^{\text {th }}$ grader identified as having Autism, has stated he will work at Amazon after high school as a software developer. Ms. Perez is now working with all her students to identify appropriate transition services (e.g., instruction, community experiences, developing adult living objectives) to support them in achieving their post-school goals. Now, her students want to explore and gather more information about these transition services to be more involved in decisions about experiences they will engage in this year to support their post-school goals.

This article provides teachers with reputable web-based resources to help youth build autonomy and gain information to support the transition from high school into post-school life. It is organized by three steps: (1): Building Autonomy to Support Successful Transition; (2)

Evaluating Web-based Resources to Explore Topics in Secondary Transition; and (3) Investigating Reputable Web-based Resources to Support Transition. This is not an exhaustive list of resources, it is merely a starting place for teachers to support student autonomy and facilitate students in learning more about themselves and the demands of future environments.

\section{Step 1: Building Autonomy to Support Successful Transition}

Autonomy refers to a students "ability to think, feel, make decisions, and act on her of his own" (Russell \& Bakken, 2002, p. 1). Building autonomy is the first step to help ensure students 
can make informed decisions related to their aspirations and choices for post-school employment, education, and independent living. It takes a lot of work to put all the pieces in place when working towards independence. There are some essential skills every youth needs for a successful transition into adulthood, including self-determination skills. Self-determination "refers to the attitudes and abilities required to act as the primary causal agent in one's life and to make choices regarding one's actions free from undue external influence or interference" (Wehmeyer, 1992, p. 305). There are many questions to explore as youth develop selfdetermination and plan for independence (e.g., Do students believe in themselves?, Do they have plans for their future?, Do students have goals and a plan to achieve those goals?).

To assist youth with disabilities in learning more about what transition planning is, teachers should first have students review Dude, Where's My Transition Plan (see http://www.peatc.org//Fact\%20Sheets/parent/Dude\%20Wheres\%20my\%20Transition\%20Plan\% 20final\%20Nov\%202014.pdf). This resource was developed by the Parent Educational and Advocacy Center in Virginia (PEATC, 2014). This resource guides students through the exploration of the questions in an easy to read, student friendly format. It includes a checklist to rate self-advocacy skills and other tools for students to begin identifying what they need to know regarding transition (e.g., health care, transportation, rights, responsibilities). Another resource is the I'm Determined website (see http://www.imdetermined.org/youth/videos/.to), which provides models of students with disabilities tackling issues of becoming self-determined. There are hundreds of videos to share with students to demonstrate they are not alone in this endeavor.

\section{Step 2: Evaluating Web-based Resources to Explore Topics in Secondary Transition}

Fortunately, there are numerous web-based resources available to students with disabilities that provide information on secondary transition topics to help youth explore the 
areas of postsecondary education and training, employment, and independent living. The internet gives students the opportunity to explore places without having to travel (e.g., virtual tours of apartments, businesses, museums). Also, it is a tool students can use to learn more about themselves and network with friends, peers, or even future employers. The internet contains some extremely valuable, high-quality information sources; however, it also contains some very unreliable, subjective sources of misinformation. Unfortunately, this is the nature of the internet. The inconsistency with the web increases the burden placed on the end user (in this case students and teachers) to evaluate the quality of each website used regardless of its intended use.

As teachers prepare youth to make informed decisions and exert a sense of autonomy, they must educate students on how to be critical consumers of information (Lucas, 2013). When investigating web-based resources for secondary transition, there is key information students should look for to feel more confident about the relevance, usefulness, and accuracy of the content being presented. First, students should determine if the site is relevant to the topic they are researching. In other words, is the website appropriate for your purposes (e.g., exploring career awareness, identifying rights and responsibilities in college)? Then, students will want to ensure the content on the website is useful to their purpose (i.e., Will it help them to make decisions about transition?). Table 1 provides information about what to look for when evaluating the reliability of a particular site (adapted from University of Wisconsin Greenbay Computing and Information Technology, 2017). If you are questioning the reliability of a site, verify information you find on the site with another source you know to be reliable.

Ms. Perez set aside time in class for students to begin exploring various websites to find more information regarding transition services and supports. Her first lesson taught students how to evaluate the websites to determine if they would be a good fit for their purpose. Each 
student selected one goal area to explore. They jotted down notes for the type of information they needed. For example, Micah wanted to know what skills were required to be a software developer. He also wanted to know how long after high school (e.g., 2-years) he would have to go to school and what he could do now to prepare. He was also curious how often he would have to interact with people on the job, as socializing is not a top priority for him.

\section{Step 3: Investigating Reputable Web-based Resources to Support Transition}

Once students have an idea of what kind of information they are looking for and how to determine if the information is trustworthy or not, they are ready to begin exploring. The following web-based resources provide information to assist youth with disabilities in planning and preparing for the transition into post-school life. These resources are a starting place for youth. For youth who are unable to evaluate whether sites are reliable or not, these resources can be bookmarked for easy access and exploration.

Resources for postsecondary education preparation. A postsecondary education experience promotes future learning and prepares individuals for a future career. Postsecondary education may (a) lead to improved outcomes in the area of employment and (b) contribute to an individual's feeling of self-confidence and self-esteem (Farrington et al., 2012). This section is designed to help students transitioning from high school to postsecondary education by providing resources for transition planning. The web-based resources are organized to support students in answering the following questions: (a) What are my postsecondary education options?; (b) What are my options for financial aid?; and (c) How do I access disability supports in postsecondary education? Table 2 provides information about each website discussed below, including the website URL and available resources. 
What are my postsecondary education options? There are different options for postsecondary education, including four-year colleges, two-year colleges, technical schools, and apprenticeships. Four and two-year colleges offer degrees and certification programs. Two-year colleges, sometimes called community colleges, or junior colleges, provide students with an opportunity to earn an associate's degree. After graduating from a two-year college, students have the option of transferring to a four-year college to complete a bachelor's degree. Technical schools and apprenticeships offer technical training in different areas such as automotive mechanics, cooking, art, dance, photography, and welding. Three reputable websites were identified that provide information (e.g., tips for good grades, accessing accommodations, searching for a college) for students with disabilities, who are interested in continuing their education after high school (see Table 2).

What are my options for financial aid? Financial aid plays an important role in supporting students with disabilities access to college. It is extremely important that youth with disabilities understand the options for financial aid, including the nuances of accessing funding. Four reputable websites have been identified that provide information (e.g., scholarships, eligibility information, award amounts) for students with disabilities, who feel they will need financial support to access college. This information may be beneficial to students and their families in making financial plans related to postsecondary education (see Table 2).

How do I access disability supports in postsecondary education? Students with disabilities preparing for college need to know the differences in legal rights between high school and college (Newman \& Madaus, 2015). To receive accommodations in college, students must disclose their disability to the Office of Disability Services on campus. In addition, students must provide appropriate documentation of disability, request accommodations, and monitor 
effectiveness (Brown \& Wolf, 2014). Two reputable websites provide information about the legal aspects related to accessing disability services on the college campus. These resources can assist students in understanding the legal aspects related to special education in postsecondary education (see Table 2).

Resources for employment preparation. Becoming an adult means having the opportunity to attain a job and earn a paycheck to purchase desired items (e.g., car, apartment, food). This section includes descriptions of reliable resources to help students find information related to career awareness, career exploration, and workplace accommodations/supports. The web-based resources are organized to help students answer the following questions: (a) What jobs match my unique strengths and interests?; (b) What skills do I need to get and keep a job?; and (c) How do I access workplace accommodations and supports? Table 3 provides information about each website discussed below, including the website URL and available resources.

What jobs match my unique strengths and interests? As teachers plan and engage in transition planning with students, it is important to understand that employment looks different for each student. Competitive employment options should be individualized and align with a students' interests, preferences, skills, and needs. The first step in finding employment is increasing awareness of not only strengths and interests, but labor market needs. To become more aware of various careers, students can learn about their preferences and aptitudes for various types of careers through assessments and other exploration activities (e.g., job shadowing, internships, career technical education classes). This process of exploration allows students to begin to make the connections between their unique strengths and interests and those needed for various careers. Five reputable websites have been identified to assist students in 
career awareness and exploration. These resources can assist students in finding a job that matches their unique strengths and interests (see Table 3).

What skills do I need to get and keep a job? Twenty-first century skills (also known as employability skills, soft skills, workplace readiness skills, career readiness skills) are general skills necessary for success in the labor market at all employment levels across disciplines (Pellegrino \& Hilton, 2012). Often students believe that because you have completed school (i.e., high school, postsecondary education) and earned a diploma that you are now eligible for a job. While this is true, getting the job and keeping the job is going to require additional $21^{\text {st }}$ century skills. Employers are looking for individuals that have the technical skills to manage the job role, as well as, other skills that will contribute to the overall success of the business (Casner-Lotto \& Benner, 2006). Four reputable websites have been identified to assist students in better understanding the skills needed for employment. These resources can assist students in attaining and retaining a job during and after high school (see Table 3).

\section{What are the legal aspects related to workplace accommodations and supports? In} addition to students having a plan and knowing their job strengths, it is important students understand legal rights and protections while on the job. These rights are called "civil rights," and the resources below will help students protect their rights. Four reputable websites provide information about the legal aspects to help students protect their rights on the job (see Table 3 ).

Resources for independent living preparation. Independent living is a philosophy and a movement by people with disabilities, who work for self-determination, equal opportunities, and self-respect. Everyone deserves the opportunity to explore living alone. Living arrangements can take many forms and vary in level of independence (e.g., apartment, group home, living with family; Ratzka, 2005). This section includes web-based resources organized to help students 
answer the following questions: (a) What are my options for transportation?; (b) What types of housing options are available?; and (c) What resources are available to support developing financial literacy skills? Table 4 provides information about each website discussed below, including the website URL and available resources.

What are my options for transportation? One of the most significant markers of the transition into adulthood is the ability to travel independently. However, accessing transportation can be one of the greatest barriers to independent living for individuals with disabilities (National Aging and Disability Transportation Center, 2017). Within most communities, there are a variety of options (e.g., public transportation, $\mathrm{Uber}^{\odot}, \mathrm{Lyft}^{\odot}$, obtaining your driver's license) that individuals can access to support independent travel. One reputable website identified provides information about travel training and embedding transportation content into educational content. This resource can assist students in accessing transportation within the community (see Table 4).

What types of housing options are available? Living arrangements need to be discussed and planned for as youth transition into adulthood. Often, youth and caregivers have different ideas and plans for future living arrangements (Henninger \& Taylor, 2014). Questions that students should consider related to providing information around housing options include: (a) Where and with whom are students going to live?; (b) Do students have a support network to support independent living?; (c) What are the housing options for individuals with disabilities within the community?; and (d) Are their housing options within the community that are near public transportation? These are all important questions for students to think about. Two reputable websites identified provide information about the different housing options and resources to support obtaining housing options of choice (see Table 4).

What resources are available to support developing financial literacy skills. Financial 
literacy is defined as "the ability to effectively use knowledge and skills to evaluate and manage one's finances in order to make wise decisions toward reaching life's goals" (Jump Start Coalition for Personal Finance Literacy, 2007, p. 3). Having finance skills requires an understanding of basic concepts of economics, money, cash flow (e.g., supply and demand, value of bills, deposits, withdrawals), and benefits planning (Jump \$tart Coalition for Personal Finance Literacy, 2007). Deficits in financial literacy skills can affect an individual's or family's day-today money management and ability to save for long-term goals (e.g., buying a car, going to college). Two reputable websites provide information about benefits planning and understanding social security benefits for individuals with disabilities (see Table 4).

Ms. Perez worked individually with all her students to identify sites that would assist them in answering the questions they had generated about transition services and supports they would need to be successful after high school. As they explored sites, they discovered services they thought would be appropriate to include in their IEP. For example, Micah learned, from exploring the Going to College Website, it would be a good idea to meet with the school career counselor to discuss colleges and requirements. He also learned it may be a good idea to register for the PSAT. Ms. Perez worked with each student to incorporate the information the students gained (e.g., assessment information, services to support achieving post-school goals) into their IEPs as part of transition services. 


\section{References}

Brown, J. T., \& Wolf, L. (2014). Transition to higher education for students with Autism Spectrum Disorder. In McPartland, J. C., Klin, A., Volkmar, F. R., \& Felder, M. A. (Eds.), Asperger Syndrome: Assessing and Treating High-Functioning Autism Spectrum Disorders (pp. 367-393). Guilford Press, NY: New York.

Casner-Lotto, J. \& Benner, M. W. (2006). Are they really ready to work: Employers perspectives on the basic knowledge and applied skills of new entrants to the $21^{\text {st }}$ century US workforce. The Conference Board, Inc, the Partnership for $21^{\text {st }}$ Century Skills, Corporate Voices for Working Families, and the Society for Human Resource Management. Retrieved from: http://www.p21.org/storage/documents/FINAL_REPORT_PDF09-29-06.pdf

Chan, P. E., Graham-Day, K.J., Ressa, V.A., Peters, M.T., \& Konrad, M. (2014). Beyond involvement: Promoting student ownership of learning in classrooms. Intervention in School and Clinic, 50, 105-113.

Farrington, C. A., Roderick, M., Allensworth, E., Nagaoka, J., Keyes, T. S., Johnson, D. W., \& Beechum, N. O. (2012). Teaching adolescents to become learners, the role of noncognitive factors in shaping school performance: A critical literature review. Consortium on Chicago School Research: University of Chicago.

Henninger, N.A., \& Taylor, J. L. (2014). Family perspectives on a successful transition to adulthood for individuals with disabilities. Intellectual and Developmental Disabilities, 52, 98-111.

Individuals with Disabilities Education Improvement Act of 2004, P. L. No. 108-446, 20 U.S.C. Jump\$tart Coalition for Personal Financial Literacy (2007). National standards in K-12 personal finance education. Retrieved from http://www.jumpstart.org/nationalstandards. 
Lucas, R. (2013). The teachers guide to keeping students safe online. Retrieved from: https://elearningindustry.com/the-teacher-guide-to-keeping-students-safe-online

National Aging and Disability Transportation Center (2017). 2016 transportation trends: A look at the year's top mobility challenges \& opportunities. Retrieved from: http://www.nadtc.org/wp-content/uploads/NADTC-Trends-Report-Mar-2017-FINAL.pdf

Newman, L. A., \& Madaus, J. W. (2015). Reported accommodations and supports provided to secondary and postsecondary students with disabilities. Career Development and Transition for Exceptional Individuals, 38, 173-181.

Parent Educational Advocacy and Training Center. (PEATC; 2014). Dude, where's my transition plan. Retrieved from:

http://www.peatc.org//Fact\%20Sheets/parent/Dude\%20Wheres\%20my\%20Transition\%20 Plan\%20final\%20Nov\%202014.pdf

Pellegrino, J. \& Hilton, M. (2012). Education for Life and Work: Developing Transferable Knowledge and Skills in the 21st Century. Washington, D.C. National Research Academy. Ratzka, A. (2005). ILI promotes the self-determination of people with disabilities. Retrieved from http://www.independentliving.org

Russell, S., \& Bakken, R. J. (2002). Development of autonomy in adolescence. University of Nebraska Lincoln. Retrieved from: http://www.basicknowledge101.com/pdf/Development\%20of\%20Autonomy\%20in\%20Ad olescence.pdf

University of Wisconsin Greenbay Computing and Information Technology (2017). How can I tell if a website is credible. Retrieved from: https://uknowit.uwgb.edu/page.php?id=30276

Wehmeyer, M.L. (1992). Self-determination and the education of students with mental retardation. Education and Training in Mental Retardation, 27, 302-314 
Table 1

Identifying a Reliable Website

\begin{tabular}{lllll}
\hline Author & Date & Sources & Domain & Writing Style \\
\hline $\begin{array}{l}\text { Look for information } \\
\text { identifying the author }\end{array}$ & $\begin{array}{l}\text { Look for a date on the } \\
\text { website and determine if } \\
\text { it is within an acceptable } \\
\text { range for your purpose } \\
\text { (e.g., does not predate } \\
\text { legal mandates such as } \\
\text { IDEA, 2004) }\end{array}$ & $\begin{array}{l}\text { Look for citations } \\
\text { included within the } \\
\text { content that tells the } \\
\text { reader where the } \\
\text { information came from }\end{array}$ & $\begin{array}{l}\text { Look at the domain (i.e., } \\
\text { is the site a .com, .org, } \\
\text {.net, .edu, .gov). Sites for poor spelling, } \\
\text { with .edu and .gov are } \\
\text { generammar, and } \\
\text { punctuation. These are } \\
\text { signs that a site is not } \\
\text { resources. The other } \\
\text { reliable. } \\
\text { purchased by individuals } \\
\text { whose intent is not }\end{array}$ \\
\end{tabular}

Note: Not all websites include all these components. If you are questioning the reliability, verify the information found with another source known to be reliable. (Adapted from University of Wisconsin Greenbay Computing and Information Technology, 2017) 
Table 2

Resources for postsecondary education preparation

\begin{tabular}{lll}
\hline Website & URL & Available Resources \\
\hline Postsecondary Education Opportunities & \\
\hline $\begin{array}{ll}\text { Going to } \\
\text { College }\end{array}$ & http://www.going-to-college.org/ & $\begin{array}{l}\text { Provides tips for good grades, accommodations, use of technology, how to use } \\
\text { strengths, learning styles, and interests to set goals for college }\end{array}$ \\
& & $\begin{array}{l}\text { Includes unique portfolio feature to help with planning, organizing and } \\
\text { collecting key documents that can be used in college and beyond }\end{array}$ \\
Think College & http://www.thinkcollege.net/ & $\begin{array}{l}\text { Provides information about the importance of college education and advice } \\
\text { from students on a variety of subjects (including a section for middle school } \\
\text { students) }\end{array}$ \\
& & $\begin{array}{l}\text { Provides Information about college programs for students with intellectual } \\
\text { disabilities }\end{array}$ \\
The College & http://collegeboard.org & - Includes features to ease the process of searching and paying for college \\
Board & & Provides a free step-by-step college guide
\end{tabular}

\begin{tabular}{ll} 
Financial Aid & \\
\hline College & $\underline{\mathrm{https}} / / /$ collegerealitycheck.com/e \\
Reality Check & $\underline{\mathrm{n} /}$
\end{tabular}

- Provides information about the cost of college education and potential future earnings

- Includes a user-friendly tool to help students find and compare colleges based on degree, size, location (state and zip code), annual net price, and graduation rate

Net Price

Calculator

http://collegecost.ed.gov/netprice

Center

Free

Application

for Federal center.aspx

http://www.fafsa.ed.gov
- Includes a net-price calculator from the U. S. Department of Education to help student determine what to expect to pay for postsecondary education

- Provides information about different types of financial aid (e.g., grants, fellowships, loans) 
Student Aid

FinAid $\quad$ http://www.finaid.org
- Includes forms and instructions for filling out financial aid applications

- Provides information about different types of financial aid (e.g., grants, fellowships, loans)

- Includes forms and instructions for filling out financial aid applications

\section{Accessing Disability Supports}

411 on $\quad$ http://www.ncwd-

Disability youth.info/assets/guides/411/411

Disability_Disclosure_complete.p

$\underline{\mathrm{df}}$

Students with http://www2.ed.gov/about/offices Disabilities /list/ocr/transition.html),

Preparing for

Postsecondary

Education
- Provides information to help students make informed decisions about disclosing their disability and understanding how it may affect their education, employment, and social lives

- Provides information about rights and responsibilities as students prepare for college

- Includes information about the obligations of a postsecondary education institution in supporting students with disabilities (e.g., providing academic accommodations, auxiliary aids and services) 
Table 3

Resources for post-school employment

\begin{tabular}{|c|c|c|}
\hline Website & URL & Available Resources \\
\hline \multicolumn{3}{|c|}{ Identifying Strengths and Interests and jobs that match } \\
\hline Youthhood & $\begin{array}{l}\text { http://www.youthhood.org/j } \\
\text { obcenter/index.asp }\end{array}$ & $\begin{array}{l}\text { - Provides tools to help students identify trengths and interests } \\
\text { - Includes interactive activities for career awareness }\end{array}$ \\
\hline $\begin{array}{l}\text { The O*NET Career } \\
\text { Exploration Tools }\end{array}$ & https://www.onetonline.org/ & $\begin{array}{l}\text { - Includes a set of career exploration and assessment tools to identify } \\
\text { work-related interests and abilities } \\
\text { - Allows students to explore jobs that match their interests, abilities, } \\
\text { and preferences. }\end{array}$ \\
\hline Rocket 21 & $\underline{\text { http://www.rocket21.com/lo }}$ & $\begin{array}{l}\text { - Provides a digital space designed to provide real-world } \\
\text { opportunities and connections for middle and high school students } \\
\text { - Experts share their views of the world and offer opportunities to } \\
\text { help students pursue their dreams. }\end{array}$ \\
\hline Virginia Career View & http://www.vacareerview.or & $\begin{array}{l}\text { - Includes information about career cluster, study and career skills } \\
\text { tips }\end{array}$ \\
\hline Career Cruising & $\begin{array}{l}\text { http://public.careercruising. } \\
\underline{\text { com/en/ }}\end{array}$ & $\begin{array}{l}\text { - Generates career profiles and allows students to engage in digital } \\
\text { learning to explore career options and create a plan to achieve goals. } \\
\text { - Membership is required to access this site }\end{array}$ \\
\hline \multicolumn{3}{|c|}{ Skills Needed to Get a Job and Keep a Job } \\
\hline $\begin{array}{l}\text { The National Collaborative } \\
\text { on Workforce and Disability }\end{array}$ & $\begin{array}{l}\text { http://www.ncwd- } \\
\text { youth.info/guideposts }\end{array}$ & $\begin{array}{l}\text { - Includes information booklets called Guideposts to help students } \\
\text { prepare for a job }\end{array}$ \\
\hline Disability.gov & https://www.disability.gov/ & $\begin{array}{l}\text { - Provides information about preparing for a job, interviewing and } \\
\text { job search skills, and self-employment }\end{array}$ \\
\hline
\end{tabular}




\begin{tabular}{ll}
\hline $\begin{array}{l}\text { Website } \\
\text { Office of Disability } \\
\text { Employment Policy }\end{array}$ & URL \\
http://www.dol.gov/odep/ \\
PACER Transition Center & $\underline{\text { http://www.pacer.org/transit }}$ \\
& $\underline{\mathrm{ion} /}$
\end{tabular}

\section{Available Resources}

- Manages a number of efforts to help students with disabilities with employment (e.g., Campaign for Disability Employment

- Provides in-person and online workshops on topics like assistive technology, postsecondary supports, and finding work in the community

\section{Accessing Workplace Accommodations and Supports}

Department of Labor Office http://www.dol.gov/odep/to

of Disability Employment pics/Accommodations.htm

Policy

Job Accommodation

Network

http://www.dol.gov/odep/re sources/jan.htm

Americans With Disabilities http://adata.org

Act National Network

The US Department of Education Office for Civil Rights (OCR)

http://www2.ed.gov/about/o ffices/list/ocr/index.html
- Provides nformation about "reasonable accommodations" that employers are required to provide employees

- Provides free, expert, and confidential guidance on workplace accommodations and disability

- Provides information about a network of 10 regional centers that offers information, guidance, and training on the American with Disabilities Act.
- Provides information about the laws that protect them, how to file a complaint if they need to, and other frequently asked questions about the civil rights of individuals with disabilities. 
Table 4

Resources for post-school independent living

\begin{tabular}{|c|c|c|}
\hline Website & URL & Available Resources \\
\hline \multicolumn{3}{|c|}{ Options for Transportation } \\
\hline Project action & $\begin{array}{l}\text { http://www.projectaction.org/Initi } \\
\text { atives/YouthTransportation/Trans } \\
\text { portationEducationCurriculum.as } \\
\text { px }\end{array}$ & $\begin{array}{l}\text { - Includes a transportation education curriculum to support educators, transit } \\
\text { professionals, families, and others with strategies for integrating } \\
\text { transportation content, including travel instruction, into the educational } \\
\text { experience }\end{array}$ \\
\hline \multicolumn{3}{|c|}{ Options for Housing } \\
\hline PACER & $\begin{array}{l}\text { http://www.pacer.org/housing/gett } \\
\text { ingstarted/housing-options.asp }\end{array}$ & $\begin{array}{l}\text { Provides rich descriptions of various housing options for individuals with } \\
\text { disabilities } \\
\text { - Provides information on existing supports available for housing. } \\
\text { - Includes information on funding sources }\end{array}$ \\
\hline $\begin{array}{l}\text { Centers for } \\
\text { Independent } \\
\text { Living }\end{array}$ & $\begin{array}{l}\underline{\text { http://www.ilru.org/projects/cil- }} \\
\underline{\text { net/cil-center-and-association- }} \\
\underline{\text { directory }}\end{array}$ & $\begin{array}{l}\text { - Provides links to Centers for Independent Living (CILs) across states. } \\
\text { - Includes information about CILs (e.g., referral, independent living skills } \\
\text { training, peer counseling, assistance with finding living arrangements) }\end{array}$ \\
\hline \multicolumn{3}{|c|}{ Financial Literacy } \\
\hline $\begin{array}{l}\text { The } \\
\text { Worksupport }\end{array}$ & $\begin{array}{l}\text { http://www.worksupport.com/reso } \\
\underline{\text { urces/listContent.cfm/4 }}\end{array}$ & $\begin{array}{l}\text { - Provides links to resources covering a wide array of topics regarding } \\
\text { benefits planning }\end{array}$ \\
\hline $\begin{array}{l}\text { The Center on } \\
\text { Transition } \\
\text { Innovations }\end{array}$ & $\begin{array}{l}\underline{\text { http://centerontransition.org/transi }} \\
\underline{\text { tion/SSABenefits/index.html }}\end{array}$ & $\begin{array}{l}\text { - Provides information to help develop a basic understanding of the Social } \\
\text { Security disability benefit program }\end{array}$ \\
\hline $\begin{array}{l}\text { National } \\
\text { Collaborative } \\
\text { on Workforce } \\
\text { and Disability }\end{array}$ & $\begin{array}{l}\text { http://www.ncwd- } \\
\text { youth.info/information-brief-16 }\end{array}$ & $\begin{array}{l}\text { - Provides overview of what financial literacy means } \\
\text { - Describes federal and state initiatives around financial literacy. } \\
\text { - Provides links to other reputable sites to learn more about managing } \\
\text { money }\end{array}$ \\
\hline
\end{tabular}

